\title{
Tournament Satisfaction Scale (TOSS)
}

\author{
Kubilay Öcal ${ }^{1}$
}

\begin{abstract}
Increasing in the popularity of regional sport tourism addresses the consumers to measure satisfaction of participants in order to provide high quality product or services. The literature declares the strong need of a reliable and valid scale in the area of sport tourism. For that purpose this paper describes the process of developing Tournament Satisfaction Scale (TOSS) that can be used to asses athletes' perception of satisfaction through sport tournaments. An item pool with 33 items was developed by literature reviews and interviews with experts in the area of sport tourism, sport management and coaching. Exploratory Factor Analysis with Maximum Likelihood extraction method and oblique rotation (direct oblimin) was carried out by using the data obtained from 278 athletes in various sport branches participated in a tournament as a regional sport tourist. Exploratory Factor Analysis results yielded one factor with 22 items over .50 factor loading. The 22 -item TOSS was found to explain $40.3 \%$ of the variance in tournament satisfaction. Cronbach alpha coefficient is 0.93 for TOSS indicating satisfactory reliability evidence. Overall, it can be concluded that the scale is reliable and valid tool for evaluating tournament satisfaction from the perceptions of athletes. In this way coaches, team managers, and tournament organizers would possible to obtain important clues about their performances.
\end{abstract}

Keywords: Sport Tourism, Tournament Satisfaction, Scale Development

\section{Introduction}

Sport tourism is the fastest growing form of tourism and it contributes to the economic development of local communities, cities, regions, and countries (Hinch \& Higham, 2011). According to Gibson (1998); sport tourism is "leisure-based travel that takes individuals temporarily outside of their home communities to participate in physical activities, to watch physical activities, or to venerate attractions associated with physical activity" (p. 49). Additionally sport tourists can be defined as "traveling individuals staying at least 24 hours in the event area and whose primary purpose is to participate in a sport event with the area being a secondary attraction" (Nogawa, Yamaguchi, \& Hagi 1996, p. 46).

The sports tourism is combination of large variety of small unit services and products in different names such as transportation, lodging, sports activities and facilities, infrastructure, natural surroundings, and social contacts that are provided in the visited region (Huang, Beeco, Hallo \& Norman, 2016; Murphy, Pritchard, \& Smith, 2000; Thwaites \& Chadwick, 2006; Tuppen, 2000). All these small units work as a gear of big wheel in order to run the system effectively.

Ziakas \& Boukas, (2013) and Gibson, Kaplanidou, \& Kang (2012) addressed the tourism potential of small scale sports events as a sport product. Interscholastic sports which are

\footnotetext{
1 Assistant Professor, Mugla Sitki Kocman University, Faculty of Sport Sciences, Department of Recreation, kubilay@mu.edu.tr
} 
considered as a form of basic student activity and a common extracurricular activity in schools (Cianfrone, Zhang, Pitts \& Byon, 2015) are small scale sports events. Thousands of student athletes participate in sports competitions at tournaments organized by School Sports Federation (SSF) and University Sports Federation (USF) in Turkey. According to the statistics; SSF is organizing sports tournament in 24 different branches in 72 different provinces during 2016. In these organizations more than 250.000 participants expected to move from cities to cities more than one times as an active participant in sport tourism. These tournaments have educational, social and economic contributions which are clearly mentioned in literature. Moreover they are also important motivators for increasing lifelong sport habits. Many athletes between ages from 5 to 25 have various social, sportive and tourism experiences which provide important contributions to their lives. Participating in these organizations strongly related to personal pleasure and it provides persistent impressions in the lives of participants (Ridinger, Funk, Jordan \& Kaplanidou, 2012). According to Sato, Jordan, and Funk (2014); event participation is an active leisure that increases the quality of life. Thus quality of the experience as a product is the most important part of sport events that consumers need to be considered (Theodorakis, Kaplanidou, \& Karabaxoglou, 2015).

Quality is characteristics of products or services that fulfill or satisfy the needs and expectations of customers. Quality in tourism has a competitive advantage (Woods \& Deegan, 2006) but also a significant contributor to the life of community (Go \& Govers, 2000). Providing a quality and satisfactory experiences increases the image of the destination and possibility to get bigger organizations. Only collective efforts given by stakeholders may succeed to realize satisfactory sports tourism experience for visitors. Managing regional sports tourism come up with collaboration of inter-sectoral actors (Currie \& Falconer, 2014; Pratt, 2015) such as municipalities, governorship, private sectors, and citizens in harmony.

Realizing the potential benefits of regional sports tourism, quality management is a critical factor. In order to provide standardized level of product for all customers there should be consensus among consumers. Interscholastic sports tournaments are national base organizations and there should be an exceptional standard for all participants to ensure equality for all citizens in the country as prerequisite of democracy.

Satisfaction is a process of comparing the gap between what was received and what was expected (Hussain, Al Nasser \& Hussain, 2015). Satisfaction involves not only customer needs and emotions as subjective factors but also product and service features as objective factors that need to be considered. There are a number of theories in literature interested in satisfaction and service paradigm. Four theoretical approaches placed under the umbrella of consistency theory which constructs the background for this study. These are Assimilation Theory, Contrast Theory, Assimilation-Contrast Theory; and Negativity Theory (Peyton, Pitts \& Kamery, 2003).

Assimilation theory originates from cognitive dissonance theory which is formulated by Kurt Lewin (Aigbavboa \& Thwala, 2013) and revised by Festinger (1957). The cognitive dissonance theory involves consumers' attempts to make cognitive comparison between expectations about the product and the perceived product performance (Tse \& Wilton, 1988). When there is a contradiction between expectations and perceived product performance, some kind of negative disconfirmation tends to arise. This perspective, defined as consumer's "postusage evaluation", was introduced into the literature as assimilation theory by Anderson (1973). According to Anderson, consumers try to find a way to avoid dissonance by adjusting their perceptions about a given product in order to balance out their expectations.

Contrast theory, on the other hand, provides an alternative view of the consumer postusage evaluation process (Hovland, Harvey \& Sherif, 1957). According to this theory; post-usage evaluations results in contradictory predictions for the outcomes of expectations on satisfaction (Cardozo, 1965). While assimilation theory suggest that consumers will try to minimize the discrepancy between expectation and performance, contrast theory on the other promote that a 
surprise effect may occurs leading to the discrepancy being magnified or exaggerated (Peyton, Pitts and Kamery, 2003)

The assimilation-contrast model is a combination of both the assimilation and the contrast theories. In this model satisfaction is a moderator of discrepancy between expected and perceived performance. According to the assimilation-contrast theory, in the situation of the small discrepancy assimilation occurs and the user will tend to adjust differences in perceptions about product performance to balance with prior expectations. When discrepancy between expectations and perceived performance is large, a contrast effects occur and the consumer tends to inflate the perceived difference (Peyton, Pitts \& Kamery, 2003), which means the product or service considered as unacceptable.

Anderson (1973) introduced Negative theory into the literature of consumer satisfaction. The theory asserts that when expectations are acutely prioritized; consumers will tend to respond negatively to any disconfirmation. Therefore, dissatisfaction will occur if perceived performance is less than expectations or if perceived performance exceed expectations (Li, Ren \& Luo, 2016).

\section{Purpose of the study}

A systematic evaluation is so critical issue to maintain service quality and satisfaction in the area of sports (Theodorakis, Alexandris, Tsigilis \& Karvounis, 2013; Yildiz \& Kara, 2012). Because service quality correlates with consumers' several psychological and behavioral responses such as involvement, identification, satisfaction, and loyalty (Brady, Voorhees, Cronin, \& Bourdeau, 2006; Ko, Kim, Kim, \& Lee, 2010; Yoshida \& James, 2010). Satisfaction with leisure activities increases life satisfaction and individual well-being among sport participants (Heo, Lee, Kim \& Stebbins, 2012; Kim, Dattilo, \& Heo, 2011, Lloyd \& Little, 2010, Chen et al. 2012). Thus this study is aimed to develop a scale to evaluate athletes' satisfaction with tournaments in terms of organization, team and individual dimensions.

\section{Methods and material Sample}

In the study, there were 278 athletes (99 female, 179 male) from 13 branches (muay thai(5), tennis(3), handball(11), track and field(17), volleyball(60), basketball(36), taekwondo(1), football(89), wrestling(3), swimming(4), orienteering (2), and others(14)). The distribution of athletes' level included school team (82), club team (95), national team (3), school/club team (78), school/club and national team (7). When we consider education level of the participants, $78 \%$ of athletes were university students, and $21 \%$ of them were high school students. Ages of the athletes vary from 13 to 39 with a mean age of $21.42 \pm 3.44$. Athletic experience in year distributed from 1 to 24 years with a mean of 8.1 and athletic experience as a tournament ratio distributed from 1 to 350 with a mean score of 19.25 .

\section{Instrumentation}

Four stages were followed in developing Tournament Satisfaction Scale (TOSS). In the first stage, a conceptual framework was developed by theoretical-rational approach (Deemer, Lin, Graham \& Soto, 2016). For the purpose of this stage, a detailed review of related literature was carried out in order to strengthen the background of the study. In the second stage of process, item pool was developed by considering previous studies and expert opinions. Sample items of the scale are: (I am satisfied with) "the harmony and friendship in my team" (during the tournament) ;( I am satisfied with) "the quality of infrastructure of the facilities" (during the tournament); (I am satisfied with) "the leisure activities" (during the tournament). After that, demographic items were added (i.e. gender, age, sport branches, education level). In the third stage, expert opinions were gathered for providing content validity of the scales. Before exploratory factor analysis, opinions from athletes, sports managers and coaches about the items in scales were taken with both written and face to face exchange of views. Contacting those people from different areas provided rich amount of feedbacks for finalizing the measure. The fourth stage was exploratory factor analysis which reveals 
factor structure of the scales and provides evidence for construct validity (Museus, Zhang \& Kim, 2016; Schiefele \& Schaffner, 2016). Each item was responded on a 9-point rating scale ranging from "very poorly" to "very well" in order to avoid difficulty in differentiating responses (Uzuntiryaki \& Aydın, 2009).

\section{Procedures}

A survey instruments were administered during 2015. Participant was given information related to the study and their written consent was obtained. No inducement or no reward was given. Completing the scale took approximately 15 minutes and participants were aware of the possibility to quit participation in any time they want. Data analysis was carried out by means of SPSS 22.0. First, descriptive statistic was used for scanning data and missing variables. Expectation of maximization was conducted in order to complete missing parts (Pampaka, Hutcheson \& Williams, 2016). Exploratory Factor Analysis with Maximum Likelihood extraction method (Fabrigar, Wegener, MacCallum, \& Strahan, 1999) and oblique rotation (direct oblimin) (Preacher \& MacCallum, 2003) was carried out by using the data obtained from 278 athletes in various branches.

\section{Result}

The sample size to item ratio (8:1) was within the range of the recommended requirements of a sample size 100 to 200 for stable factor solutions (Field, 2005; Guadagnoli \& Velicer, 1988; Hair, 1995). Prior to analysis, data were examined for accuracy of its entry and missing values. There existed no missing values greater than $5 \%$ in entire data. Exploratory factor analyses results are summarized in Table 1 which provides factor loadings and item-total correlations and alpha coefficients if item deleted.

Table 1. Summary of Factor Analysis Result of TOSS

\begin{tabular}{lccc}
\hline & Factor Loadings & Item-Total Correlation & Alpha If Item Deleted \\
\hline Item 16 & 0.72 & 0.68 & 0.92 \\
Item 13 & 0.72 & 0.67 & 0.92 \\
Item 20 & 0.71 & 0.66 & 0.92 \\
Item 11 & 0.67 & 0.92 \\
Item 15 & 0.71 & 0.64 & 0.92 \\
Item 12 & 0.70 & 0.66 & 0.92 \\
Item 7 & 0.69 & 0.64 & 0.92 \\
Item 8 & 0.69 & 0.63 & 0.92 \\
Item 10 & 0.68 & 0.60 & 0.92 \\
Item 5 & 0.66 & 0.59 & 0.92 \\
Item 14 & 0.65 & 0.58 & 0.92 \\
Item 6 & 0.64 & 0.58 & 0.92 \\
Item 21 & 0.64 & 0.60 & 0.92 \\
Item 9 & 0.64 & 0.59 & 0.92 \\
Item 4 & 0.64 & 0.54 & 0.92 \\
Item 22 & 0.63 & 0.55 & 0.92 \\
Item 19 & 0.59 & 0.51 & 0.92 \\
Item 3 & 0.58 & 0.50 & 0.92 \\
Item 18 & 0.56 & 0.49 & 0.92 \\
Item 17 & 0.53 & 0.45 & 0.92 \\
Item 2 & 0.52 & 0.45 & 0.92 \\
Item 1 & 0.50 & & 0.92 \\
\hline
\end{tabular}


As suggested by Field (2005); both eigenvalues and scree plot was used to examine the factor structure of the scale. Although there were two factors whose eigenvalues are greater than 1 , explained variance by factor two was less than $5 \%$. Also the scree plot for data shows that there is only one underlying factor and thus it was concluded that one factor structure, explaining $40.30 \%$ of the variance, is more suitable for this scale. For the reliability evidence of TOSS, Cronbach alpha was calculated. Cronbach alpha for the scale was .93 , which provides satisfactory evidence for reliability.

\section{Discussion}

This study describes development process of Tournament Satisfaction Scale (TOSS). First of all, in order to provide content validity extensive review of literature and expert opinion obtained by dialogue with sport managers, athletes, coaches and tournament organizers. An item pool was developed after providing theoretical basis. Thirty three items was generated for six dimensions hypothesized to correlate with athletes' tournament satisfaction. These hypothesized dimensions are; athletes' own performance, the overall team performance and interpersonal relations among team members, the managers and coach's performance and positive behaviors during the tournament, the service and organizational performance provided by host city, and the interaction with other teams, provided leisure activities and features of host destination. The scale with thirty three items and seven demographic questions was conducted to 278 athletes in order to test the factorial structure of the scale, scale reliability and validity evidence. The sample size of this study meets the recommended criteria proposed by Cattell, (1978) and Comrey and Lee, (1992). Exploratory Factor Analysis with Maximum Likelihood extraction method and oblique rotation (direct oblimin) was carried out. Results provide one factor with 22 items over .50 factor loadings (Costello \& Osborne, 2005). The items lower than these criteria were deleted. The 22-item TOSS was found to measure $40.3 \%$ of the variance in tournament satisfaction. According to the Sherer, Wiebe, Luther, and Adams (1988); this score is satisfactory for social sciences. Analysis of internal consistency reliabilities yielded Cronbach alpha coefficients of 0.93 for TOSS indicating satisfactory reliability. Furthermore, examining item-total correlations indicated that all items in each dimension contributed to the consistency of scores with item-total correlations higher than 0.40 (Field, 2005).

According to the findings I am confidentially argue that the scale which have sufficient reliability and validity evidence can be use in the area of both sport and tourism management. The advantage of this scale is having items that related to customer satisfaction, athlete's satisfaction and service quality at the same time. This increases the usability of scale in different areas. In parallel studies Confirmatory factor Analysis toke place in the next step. Such kind of studies in literature should be planned carefully in order to keep the main structure. Although the scale explains sufficient variance in tournament satisfaction, adding new items and factors will extend the scope of scale. So, more comprehensive data will be gathered about athlete's satisfaction.

Developing a scale for evaluating tournaments satisfaction is an important issue because satisfaction is directly related to intention to participate in the following events. Satisfactory sport environments during the sport tournaments would affect the future participation in sport (Kaplanidou \& Gibson, 2010). This would create a basis for healthy society.

\section{Conclusion and recommendation}

Managers suggest that we can't manage things that we cannot measure. This scale will help for measuring the strength and weaknesses of tournaments from the perspective of athletes who are the most important elements of sports and sports tourism. With the help of this scale coaches, team managers, and tournament organizers can evaluate their performance which in turn to achieve better in their duties.

Besides providing a valid and reliable instrument to the literature, this study also emphasizes the benefits of interscholastic sport tournaments as small scale events organized in various cities in Turkey. Thousands of student athletes, trainers, referees and managers move from one destination 
to another in several times of a year. By the way, they can develop social networks and connections between regions. Additionally, this mobility also contributes economic development of host cities, social and educational development of individuals clearly. Maximizing the advantage of these activities in every dimension provided by regional sport tourism, cooperation between all stakeholders is strongly recommended. This cooperation helps to increases the image of the local destination which has positive correlation with satisfaction of the participators. Moreover this cooperation is a useful tool for providing satisfactory sport experiences for all. In this way it would be possible to increase the sport participation in Turkey which has the lowest proportion in Europe (Turkish Ministry of Health, 2013). However further researches are needed to identify other variables of tournament satisfaction. Although we believe that this study provides a comprehensive analysis, the study has some limitations. It should be considered that the finding based on qualitative data that is not really allows in-depth understanding. In case quantitative research asking athletes tournament satisfaction in detailed will provides new and interesting data and results. Thus mix studies will be more appropriate in future researches about athlete's tournament satisfaction.

This study points to some other directions for further research. As we mentioned before organization in sports tourism is a challenging but important field for research. It is high societal relevance, affecting a large number of people, both sport tourists and inhabitants of that region. So that there should be more research to gain a better evaluation in turn to developing the market and satisfying customer needs in best way.

\section{Acknowledgement} study.

We would like to thank to Dr. Gulfem Cakır for her contributions during the process of this

\section{References}

Aigbavboa, C. \& Thwala W., (2013) A Theoretical Framework of Users' Satisfaction/Dissatisfaction Theories and Models, 2nd International Conference on Arts, Behavioral Sciences and Economics Issues (ICABSEI'2013) Dec. 17-18, 2013 Pattaya (Thailand) 48-53.

Anderson, R.E. (1973) Consumer Dissatisfaction.: The Effect of Disconfirmed Expectancy on Product Performance, Journal of Marketing, Research, 10, p.38-44. DOI:10.2307/3149407

Bandura, A. (1997). Self-efficacy: The exercise of control. New York: Freeman.

Bandura, A. (2001). Guide for constructing self-efficacy scales (revised). Retrieved May 26, 2005 from http://www.emory.edu/EDUCATION/mfp/banduraguide.html

Boukas, N., \& Ziakas, V. (2016). Tourism policy and residents' well-being in Cyprus: Opportunities and challenges for developing an inside-out destination management approach. Journal of Destination Marketing \& Management. DOI:10.1016/j.jdmm.2015.12.004

Brady, M. K., Voorhees, J. J., Cronin, Jr., J., \& Bourdeau, B. L. (2006). The good guys don't always win: The effect of valence on service perceptions and consequences. Journal of Services Marketing, 20, 83-91. DOI:10.1108/08876040610657011

Cardozo, R. (1965). An experimental Study of Customer Effort, Expectation, and Satisfaction", Journal of Marketing Research, 2(8), 244-249. DOI:10.2307/3150182

Cattell, R. B. (1978). The Scientific Use of Factor Analysis. New York: Plenum.

Chen, L. H., Chen, M. Y., Ye, Y. C., Tung, I. W., Cheng, C. F., \& Tung, S. (2012). Perceived service quality and life satisfaction: The mediating role of the actor's satisfaction-withevent. International Journal of Sports Marketing and Sponsorship, 13(4), 249-266. DOI:10.1108/IJSMS-13-04-2012-B003

Cianfrone, B. A., Zhang, J., Pitts, B., \& Byon, K. K. (2015). Identifying key market demand factors associated with high school basketball tournaments. Sport Marketing Quarterly, 24(2), 91. 
Comrey, A. L., \& Lee, H. B. (1992). A first Course in Factor Analysis. Hillsdale, NJ: Erlbaum.

Costello, A. B., \& Osborne, J. W. (2005). Best practices in exploratory factor analysis: Four recommendations for getting the most from your analysis. Practical Assessment Research \& Evaluation, 10(7). Retrieved February 21, 2016 from http://pareonline.net/pdf/v10n7.pdf.

Currie, C., \& Falconer, P. (2014). Maintaining sustainable island destinations in Scotland: The role of the transport-tourism relationship. Journal of Destination Marketing \& Management, 3(3), 162-172. DOI:10.1016/j.jdmm.2013.10.005

Deemer, E. D., Lin, C., Graham, R., \& Soto, C. (2016). Development and Validation of a Measure of Threatening Gender Stereotypes in Science A Factor Mixture Analysis. Journal of Career Assessment, 24(1), 145-161.

Fabrigar, L. R., Wegener, D. T., MacCallum, R. C., \& Strahan, E. J. (1999). Evaluating the use of exploratory factor analysis in psychological research. Psychological methods, 4(3), 272.

Festinger, L. (1957), A theory of cognitive dissonance, Stanford: Stanford Press.

Field A. (2005). Discovering Statistics Using SPSS (2nd Edition.). Londra: Sage.

Gibson, H. J. (1998). Sport tourism: a critical analysis of research. Sport management review, 1(1), 4576.

Gibson, H. J., Kaplanidou, K., \& Kang, S. J. (2012). Small-scale event sport tourism: A case study in sustainable tourism. Sport Management Review, 15(2), 160-170.

Go, F. M., \& Govers, R. (2000). Integrated quality management for tourist destinations: a European perspective on achieving competitiveness. Tourism Management, 21(1), 79-88.

Guadagnoli, E., \& velicer, W. F. (1988). Relation of sample size to the stability of component patterns. Psychological bulletin, 103, 265-275.

Hair, J. F. J., Anderson, R. E., Tatham, R. L., \& Black,W. C. (1995). Multivariate data analysis (4th ed.). Saddle River, NJ: Prentice Hall.

Heo, J., Lee, I. H., Kim, J., \& Stebbins, R. A. (2012). Understanding the relationships among central characteristics of serious leisure: An empirical study of older adults in competitive sports. Journal of Leisure Research, 44(4), 450.

Hinch, T., \& Higham, J. (2011). Sport tourism development (Vol. 13). Channel view publications.

Hovland, C. I., Harvey, O. J., \& Sherif, M. (1957). Assimilation and contrast effects in reactions to communication and attitude change. The Journal of Abnormal and Social Psychology, 55(2), 244.

Hoyer, W. D. \& Mac Innis, D. J., 2001, Consumer Behaviour. 2nd ed., Boston, Houghton Mifflin Company.

Huang, W. J., Beeco, J. A., Hallo, J. C., \& Norman, W. C. (2016). Bundling attractions for rural tourism development. Journal of Sustainable Tourism, 1-16.

Hussain, R., Al Nasser, A., \& Hussain, Y. K. (2015). Service quality and customer satisfaction of a UAE-based airline: An empirical investigation.Journal of Air Transport Management, 42, 167175.

Jae Ko, Y., Kyoum Kim, Y., Kil Kim, M., \& Hak Lee, J. (2010). The role of involvement and identification on event quality perceptions and satisfaction: A case of US Taekwondo Open. Asia Pacific Journal of Marketing and Logistics,22(1), 25-39.

Kaplanidou, K., \& Gibson, H. J. (2010). Predicting behavioral intentions of active event sport tourists: The case of a small-scale recurring sports event.Journal of Sport \& Tourism, 15(2), 163-179. DOI:10.1080/14775085.2010.498261

Kaplanidou, K., \& Vogt, C. (2007). The interrelationship between sport event and destination image and sport tourists' behaviours. Journal of Sport \& Tourism, 12(3-4), 183-206. DOI:10.1080/14775080701736932

Kelley, S. W., \& Turley, L. W. (2001). Consumer perceptions of service quality attributes at sporting events. Journal of Business Research, 54(2), 161-166. 
Kim, J., Dattilo, J., \& Heo, J. (2011). Taekwondo participation as serious leisure for life satisfaction and health. Journal of Leisure Research, 43(4), 545.

Li, Y., Ren, L., \& Luo, F. (2016). Is bad stronger than good? The impact of police-citizen encounters on public satisfaction with police. Policing: An International Journal of Police Strategies \& Management, 39(1).

Lloyd, K., \& Little, D. E. (2010). Self-determination theory as a framework for understanding women's psychological well-being outcomes from leisure-time physical activity. Leisure Sciences, 32(4), 369-385. DOI:10.1080/01490400.2010.488603

Murphy, P., Pritchard, M. P., \& Smith, B. (2000). The destination product and its impact on traveller perceptions. Tourism management, 21(1), 43-52. DOI:10.1016/S02615177(99)00080-1

Museus, S. D., Zhang, D., \& Kim, M. J. (2016). Developing and Evaluating the Culturally Engaging Campus Environments (CECE) Scale: An Examination of Content and Construct Validity. Research in Higher Education, 1-26. DOI:10.1007/s11162-015-9405-8

Nogawa, H., Yamaguchi, Y., \& Hagi, Y. (1996). An empirical research study on Japanese sport tourism in sport-for-all events: Case studies of a single-night event and a multiple-night event. Journal of Travel Research, 35(2), 46-54. DOI:10.1177/004728759603500208

Pampaka, M., Hutcheson, G., \& Williams, J. (2016). Handling missing data: analysis of a challenging data set using multiple imputation. International Journal of Research \& Method in Education, 39(1), 19-37. DOI:10.1080/1743727X.2014.979146

Parker, C., \& Mathews, B. P. (2001). Customer satisfaction: contrasting academic and consumers' interpretations. Marketing Intelligence \& Planning,19(1), 38-44. DOI:10.1108/02634500110363790

Peyton, R. M., Pitts, S., \& Kamery, R. H. (2003). A review of significant consumer satisfaction/dissatisfaction models: The family decision-making process. In Proceedings of the Academy of Family Business (Vol. 1, No. 2, pp. 3-8).

Pratt, S. (2015). The economic impact of tourism in SIDS. Annals of Tourism Research, 52, 148-160. DOI:10.1016/j.annals.2015.03.005

Preacher, K. J., \& MacCallum, R. C. (2003). Repairing Tom Swift's electric factor analysis machine. Understanding statistics: Statistical issues in psychology, education, and the social sciences, 2(1), 13-43.

Ridinger, L. L., Funk, D. C., Jordan, J. S., \& Kaplanidou, K. K. (2012). Marathons for the masses: Exploring the role of negotiation-efficacy and involvement on running commitment. Journal of Leisure Research, 44(2), 155.

Sato, M., Jordan, J. S., \& Funk, D. C. (2014). The role of physically active leisure for enhancing quality of life. Leisure Sciences, 36(3), 293-313. DOI:10.1080/01490400.2014.886912

Scherer, R. F., Wiebe, F. A., Luther, D. C., \& Adams, J. S. (1988). Dimensionality of coping: Factor stability using the ways of coping questionnaire. Psychological Reports, 62(3), 763-770. DOI:10.2466/pr0.1988.62.3.763

Schiefele, U., \& Schaffner, E. (2016). Factorial and Construct Validity of a New Instrument for the Assessment of Reading Motivation. Reading Research Quarterly. DOI: 10.1002/rrq.134

St Leger, A. S., Schnieden, H., \& Walsworth-Bell, J. P. (1992). Evaluating Health Services' Effectiveness: A Guide for Health Professionals, Service Managers and Policy Makers. Open University Press.

Theodorakis, N. D., Alexandris, K., Tsigilis, N., \& Karvounis, S. (2013). Predicting spectators' behavioural intentions in professional football: The role of satisfaction and service quality. Sport Management Review, 16(1), 85-96. DOI:10.1016/j.smr.2012.05.004

Theodorakis, N. D., Kaplanidou, K., \& Karabaxoglou, I. (2015). Effect of Event Service Quality and Satisfaction on Happiness Among Runners of a Recurring Sport Event. Leisure Sciences, 37(1), 87-107. DOI:10.1080/01490400.2014.938846 
Thwaites, D., \& Chadwick, S. (2006). Service quality perspectives in sport tourism. In H. Gibson (Ed.), Sport tourism. Concepts and theories (pp. 189205). New York, NY: Routledge. DOI:10.1080/17430430500087781

Tse, D. K., \& Wilton, P. C. (1988). Models of consumer satisfaction formation: An extension. Journal of marketing research, 204-212. DOI:10.2307/3172652

Tuppen, J. (2000). The restructuring of winter sports resorts in the French Alps: Problems, processes and policies. The International Journal of Tourism Research, 2(5), 327.

Turkish Ministry of Health (2013). Türkiye balk sağhğg kurumu, Türkiye sağhlkh beslenme ve bareketli hayat programi, (2013-2017) Ankara.

Uzuntiryaki, E., \& Aydın, Y. Ç. (2009). Development and validation of chemistry self-efficacy scale for college students. Research in Science Education, 39(4), 539-551. DOI:10.1007/s11165-008-9093-x

Woods, M., \& Deegan, J. (2006). The impact of training on interfirm dynamics within a destination quality network: The Case of the Fuchsia Brand, Ireland. Advances in Hospitality and Leisure, 2, 25-50.

Yildiz, S. M., \& Kara, A. (2012). A re-examination and extension of measuring perceived service quality in physical activity and sports centres (PSC): QSport-14 scale. International Journal of Sports Marketing and Sponsorship, 13(3), 26-45.

Yoshida, M., \& James, J. D. (2010). Customer satisfaction with game and service experiences: Antecedents and consequences. Journal of sport management, 24(3), 338-361.

Ziakas, V., \& Boukas, N. (2013). Extracting meanings of event tourist experiences: A phenomenological exploration of Limassol carnival. Journal of Destination Marketing \& Management, 2(2), 94-107. DOI:10.1016/j.jdmm.2013.02.002

\section{Appendix}

\section{Items of the scale}

1. Takım içindeki uyum ve arkadaşlık

2. Takımın sağladığı malzeme ve kıyafet kalitesi

3. Sağlıklı ve lezzetli beslenme olanakları

4. Konaklama alanlarındaki hizmet ve altyap kalitesi

5. Antrenörlerin tavır ve davranışları

6. Müsabaka alanında antrenman olanağ1

7. Antrenörlerin deneyim ve organizasyon yetenekleri

8. Turnuvada sağlanan antrenman ve hazırlanma olanakları

9. İdarecilerin tavır ve davranışları

10. Organizasyonda verilen sağllk hizmetleri

11. Konaklama ve müsabaka yeri arasındaki ulaşım olanakları

12. Turnuva ile ilgili ön tanıtım ve bilgilendirme

13. Takımlara sunulan eşit ve tarafsız hizmet anlayışı

14. Organizasyonun ilan edilen programa uygun gerçekleşmesi

15. Organizasyondan sorumlu kişilere kolayca ulaşabilme

16. Yetkililerin problem çözme ve kriz yönetimindeki başarısı

17. Serbest zaman aktiviteleri (şehir turları, alışveriş vs.)

18. Haberleşme ve internet olanakları

19. Branştaki popüler sporcu ve antrenörlerle tanışama olanağ

20. Takımlar arası saygı, anlayış ve centilmenlik.

21. İzleyicilerin tavır ve davranışları

22. Turnuvada alınan ödül/derece/saygınlık 